\title{
A Grisaille Oil Sketch from the "De Backer Group" and Workshop Practices in Sixteenth-Century Antwerp
}

\author{
ECKHARD LEUSCHNER \\ Associate Professor, University of Passau
}

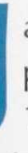

acob (also known as Jacques) de Backer, a painter praised by Karel van Mander in his Schilder-Boeck of 1604, remains a problematic figure in the history of late sixteenth-century Netherlandish art. None of the pictures mentioned as his works in the Schilder-Boeck can be securely identified; ${ }^{1}$ no painting or drawing attributed to him carries a signature with any claim to authenticity; and, despite the admirable efforts of Justus Müller Hofstede and Leen Huet, scholars agree neither on his approximate life span nor on the definitive scope of his oeuvre. ${ }^{2}$ The art trade, however, continues to baptize as "De Backer" particular kinds of paintings and drawings: allegorical, mythological, and religious subjects that were clearly made in the Southern Netherlands between about 1570 and 1600 but that at the same time display a strong influence of the late Italian maniera. (Indeed, during their previous stint in the art market many of the pictures now given to De Backer carried an attribution to Italian painters such as Agnolo Bronzino, Francesco Salviati, and Jacopo Zucchi.) The works currently assigned to Jacob de Backer exhibit surprising differences in artistic quality and, within the defining frame of late sixteenth-century Netherlandish Romanism, represent a plurality of individual substyles. The situation is further complicated by the fact that nearly every painting attributed to the artist is known in two or more (sometimes as many as twenty) versions. ${ }^{3}$

In previous publications, ${ }^{4}$ I have suggested strategies for approaching the De Backer phenomenon in order to create a more convincing profile of the artist. I called for a close reading of written sources and provenance information and a study of iconographic parallels and the evidence of prints inscribed with a "De Backer invenit." But my ultimate suggestion was that we shift our attention away from the previous quest, often unsuccessful, to isolate original pictures by a distinct personality called Jacob de Backer and concentrate on defining a corpus of works closely related in style and iconography that we might label "the De Backer group." Only after such a group has been identified and studied systematically can we even begin to define individual hands within it, among them Jacob de Backer, who indeed might be better characterized as a workshop head than as a master. De Backer is never mentioned as a master in the Antwerp Liggeren, or Record of Artists. As Van Mander implied, he worked in the studio of the art dealer and painter Antonio van Palermo (1503/13-before 1589).

Even though a considerable number of previously unknown Southern Netherlandish Mannerist pictures come to light each year, scholarly efforts in the field remain sparse. And recent academic publications devoted to the philosophy of the multiplied image in Netherlandish art have contributed little to a better understanding of the actual mechanics of workshop production in the fifteenth and sixteenth centuries. ${ }^{5}$ The most promising method of dealing with the mass of replications, variations, and copies attributed to Jacob de Backer remains a close examination of the stylistic and material evidence of each work in conjunction with an analysis of its function. Studying the relationship between the different versions of a single composition can then help to reveal how the choice of particular artistic means was connected with contemporary workshop practice and the tastes of patrons and art collectors.

A case in point is a heretofore unpublished chiaroscuro oil on paper (Figure 1) acquired in 2002 by the Department of Drawings and Prints of The Metropolitan Museum of Art as a work attributed to Jacob de Bàcker. ${ }^{6}$ As a recent restoration has confirmed, the paper was originally laid down on panel; traces of the wood grain are still visible on the verso of the cardboard on which the drawing is now pasted. The verso of the cardboard (Figure 2) also contains traces of a drawing in black chalk depicting the torso and head of a seated woman with a naked child standing on her leg. The oil itself (for which the chalk drawing may have served as a preparatory study) shows a seated Madonna gazing down at the infant Christ she cradles in her right arm. Jesus, positioned securely on the massive limbs of his mother, looks up at her as he stretches his left arm toward the apple she holds up in her left hand. Although there is no indication of the throne or chair Mary is sitting on, the plinth that raises her figure slightly 
1. The De Backer group (active Antwerp, ca. 1570-1600). Charity, or, Madonna and Child with Saint John, ca. 1580-90. Brown and black oil with white heightening on paper, $115 / 8 \times 9$ in. $(29.5 \times 23 \mathrm{~cm})$. The Metropolitan Museum of Art, The Elisha Whittelsey Collection, The Elisha Whittelsey Fund, 2002 (2002.88)

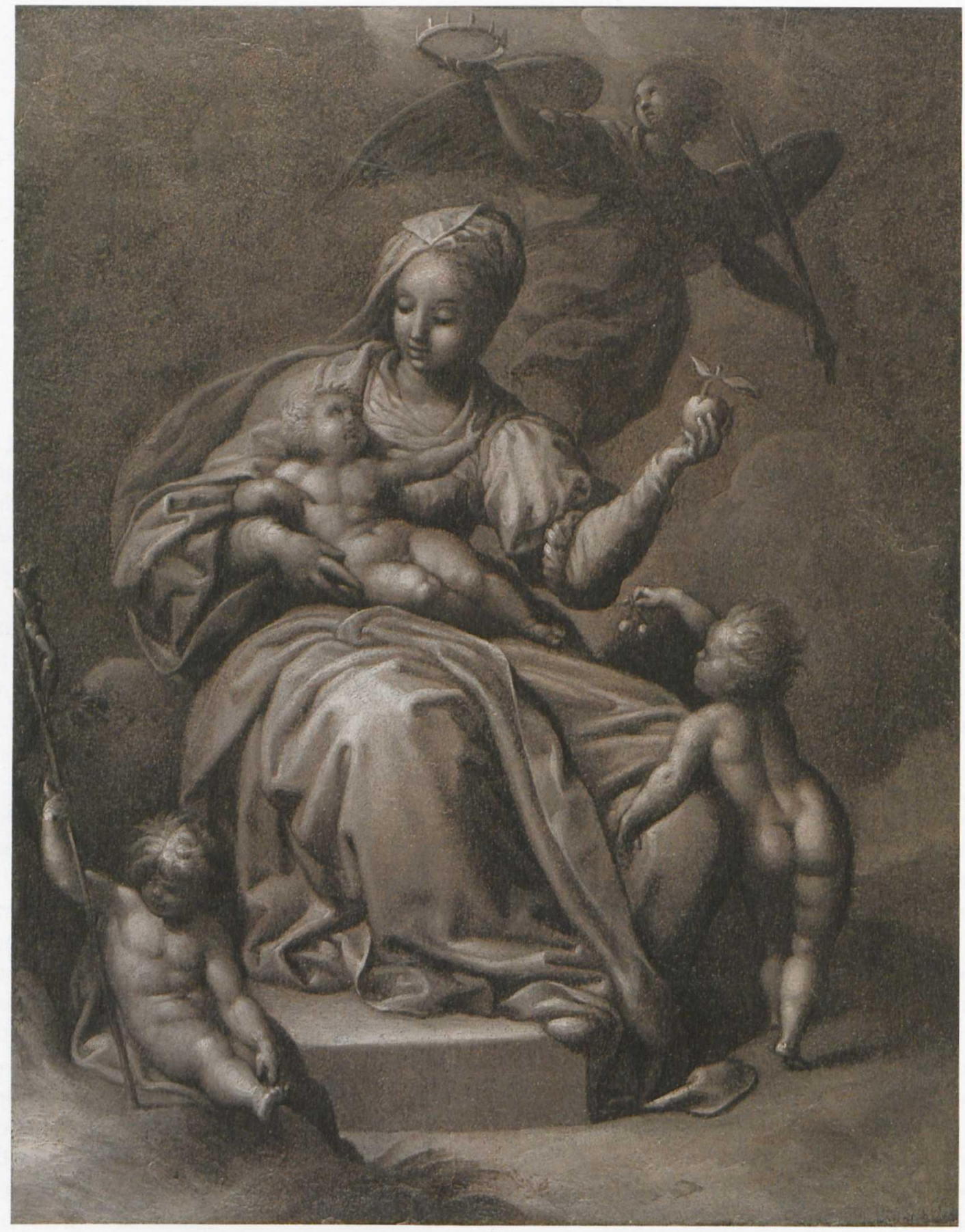

above ground level lends her dignity. Her elegant headgear covers most of her hair. The bodice and sleeves of her dress are of more refined cloth than the massive folds of drapery winding around her volumetrically defined legs and falling over the edge of the plinth to the ground. The angel poised in the air behind the Virgin, beyond the light that illuminates the figures in the foreground, holds a crown over her head with his right hand and a palm frond in his left. The naked child at the right raises his right arm to offer two cherries to the infant Christ, and as he does so turns his back to the spectator in an elegant walking pose that was popular with other sixteenthcentury painters. ${ }^{7}$ The child sitting on a slightly elevated spot in the left foreground that may be the roots of a tree, his face almost completely in shadow, holds an anachronistic crucifix that clearly identifies him as the young Saint John, the forerunner of Christ.

The unusual combination of motifs in this picture evinces its maker's intense study of Italian models, earlier Netherlandish images inspired by Italian art, or both. Jacques Foucart, followed by Leen Huet, has compared the nude child presenting the cherries to Jesus to the figure of Cupid in Agnolo Bronzino's Felicitas Publica in the Uffizi, Florence, ${ }^{8}$ but this motif is more probably a free interpretation of the famous Rest on the Flight to 


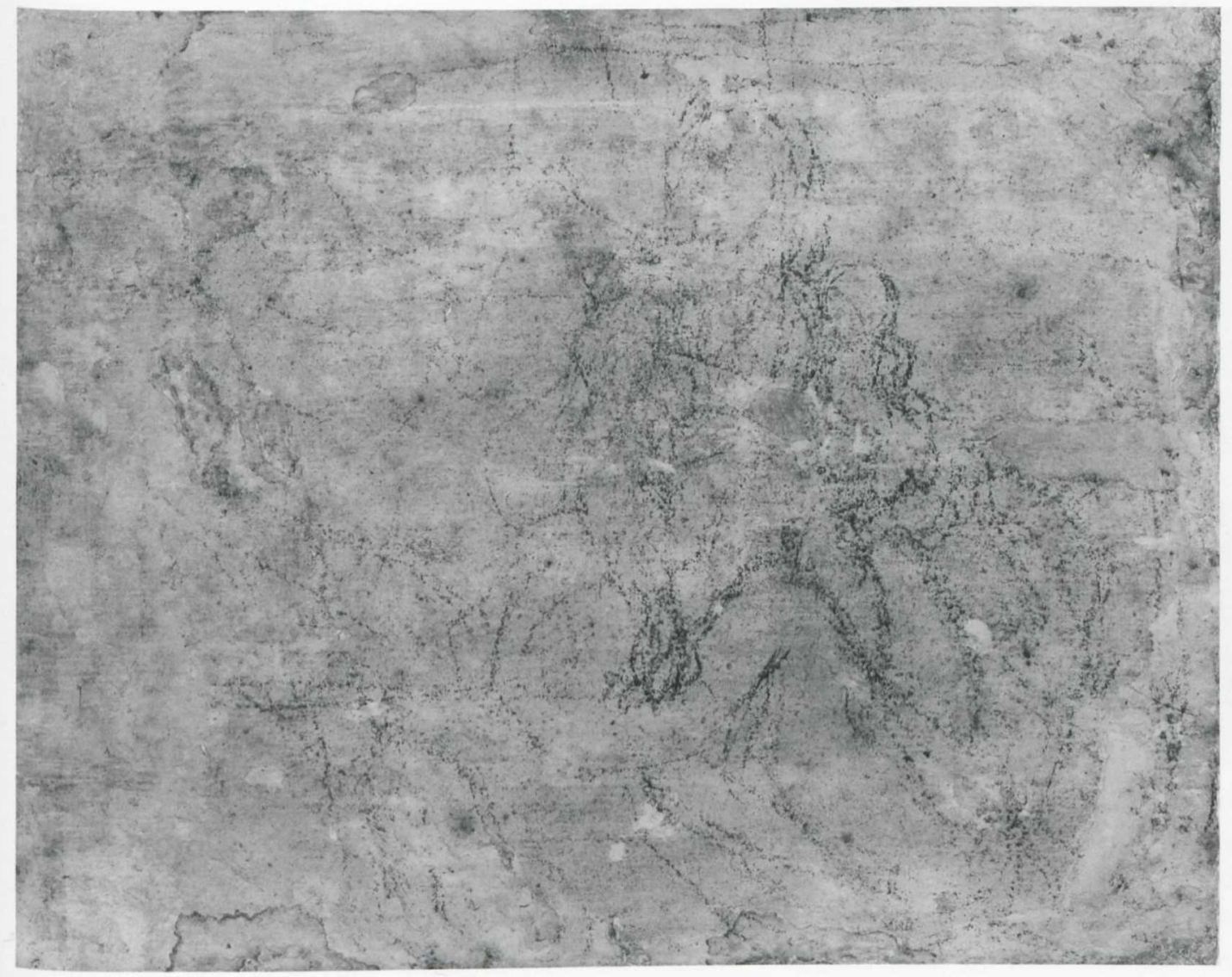

2. The De Backer group. Torso and Head of a Woman with a Child Standing on Her Lap (verso of Figure 1). Black chalk

Egypt by Federico Barocci that Cornelis Cort reproduced in $1575 .{ }^{9}$ The interaction between a seated Mary holding an apple and the infant Jesus appears in other contemporary compositions, among them Adriaen Collaert's Holy Family after Hendrick Goltzius of $1585 .{ }^{10}$ The massive figure of Mary seated on a plinth derives from sculptural representations of the Virgin and Child such as the famous Madonna of Bruges by Michelangelo (Onze Lieve Vrouwekerk, Bruges). Her weighty, volumetric figure is closely related to other Madonnas attributed to the De Backer group, most significantly the Madonna and Child with Saint John in the Kunsthistorisches Museum, Vienna (Figure 3). ${ }^{11}$

Not surprisingly for a picture associated with the De Backer group, the New York oil on paper is closely related to several other compositions. Another rendering, in black chalk and white heightening on blue paper, is in the Dresden Kupferstich-Kabinett (Figure 4). ${ }^{12}$ That sheet, also previously unpublished, is slightly disfigured by oil stains in the upper half, but their presence does not obliterate the composition's attractions. The number 1583 , which may be either a date or an inventory number, has been added in black ink in the lower right corner. The slightly hesitant drawing style of the Dresden work indicates that it was copied by a studio apprentice or follower after a superior version, perhaps an as yet untraced work on paper.
At least two paintings are connected with the composition of the New York oil sketch. One, on canvas (Figure 5), is in the church of Saint-Germain-d'Auxerre in Boissise-laBertrand; the other, on panel and of slightly inferior quality (Figure 6), was sold at Sotheby's in London in 1977 and has not been seen since. ${ }^{13}$ The painting in France, which the American art dealer and collector George Aloysius Lucas presented to the church of Boissise-la-Bertrand in 1894, carried an attribution to Andrea del Sarto until Foucart published it as a work of De Backer in $1988 .{ }^{14}$ The painting is a particularly successful translation of the sculptural or relieflike qualities expressed in the New York oil sketch in a colorful arrangement of tastefully positioned figures whose marble white skin is enhanced by touches of elegant if somewhat unnatural colors. Did Karel van Mander base his praise of Jacob de Backer as an excellent colorist on this kind of picture?

The New York oil served either as a modello for a painting, a record of a canvas or panel version after it had left the workshop, or a finished painting sui iuris that, like the versions on canvas and panel, was sold to a collector. Considering that the work was laid down on wood for a long time, it is tempting to assume a combination of either the first and third or the second and third functions. The New York grisaille may even be the "work in white and black by Jacques de Backer, a Charity on panel in a frame" 


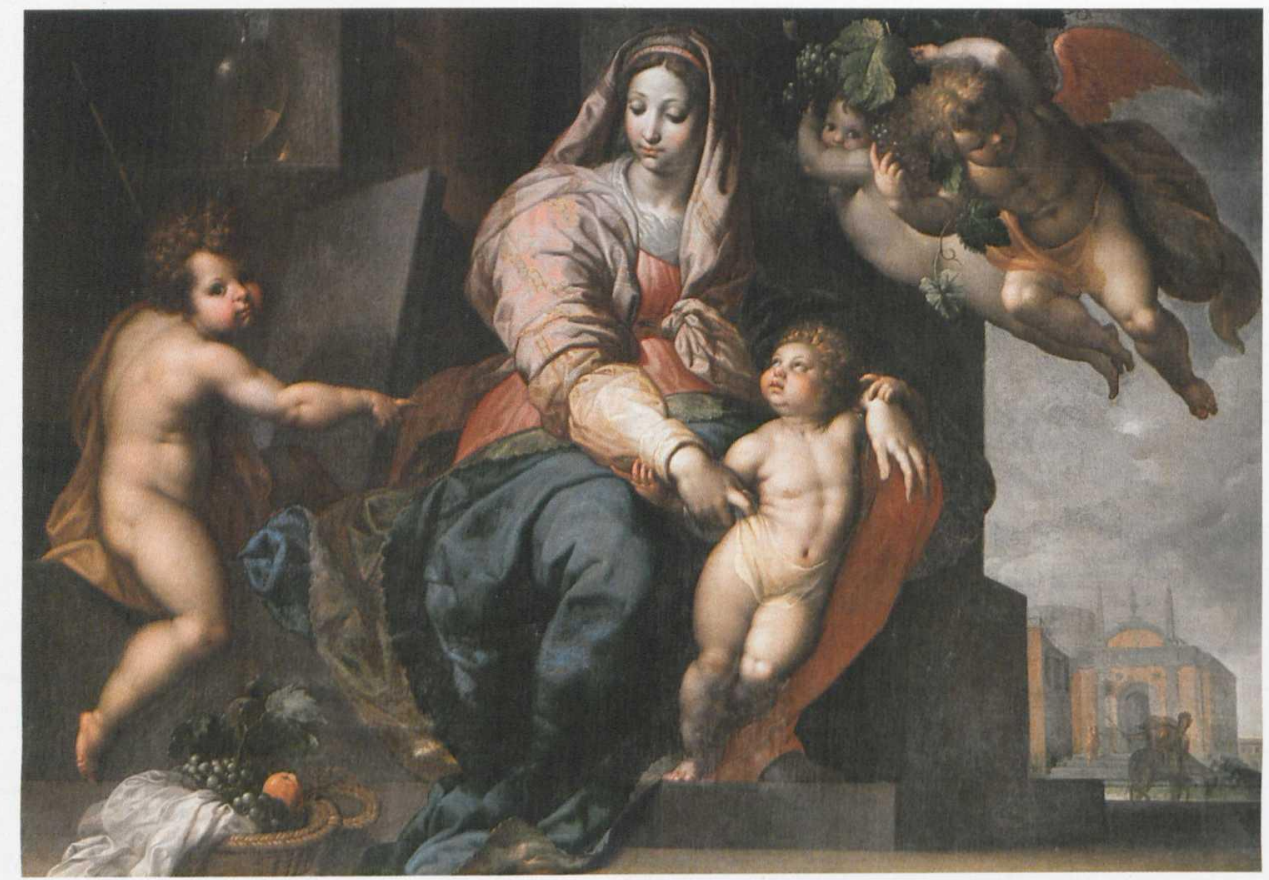

3. The De Backer group. Madonna and Child with Saint John. Oil on canvas, $523 / 8 \times 71$ in. $(133 \times 180.5$ $\mathrm{cm})$. Kunsthistorisches Museum, Vienna (1689). Photograph: Erich Lessing / Art Resource, New York mentioned in the inventory of the collection of the painter Victor Wolfvoet at the time of his death in Antwerp in $1652 .{ }^{15}$ If, as the traces of black chalk on the verso of the sheet indicate, the paper was reused by the same artist or group of artists, the mounting and perhaps even the paneling of the grisaille could have been done in the same shop. It may have been intended to be seen as a painting from the very beginning.

The oil "sketch" in the Metropolitan Museum has little to do with the free and more painterly monochrome oils by Italian cinquecento artists such as Federico Barocci or Jacopo Tintoretto but is related instead to the clearly defined, relieflike chiaroscuro produced in sixteenth-century Florence, most prominently by artists in the circle of Giorgio Vasari such as the Netherlandish painter Joannes Stradanus (or Jan van der Straet). ${ }^{16}$ The parallel with Stradanus is one of style rather than technique. His grisaille paintings were in either fresco or tempera, and none of his works on paper appears to have been made in the medium of oil. Yet the figure style and distribution of light and shadow in some of his more finished drawings, especially those that served as models for Medici tapestries and were later sent to Antwerp to be turned into engravings, are remarkably analogous to the Metropolitan painting.

In the sixteenth century several artists in the Netherlands made monochrome oil drawings on paper, ${ }^{17}$ among them Joachim Beuckelaer, ${ }^{18}$ Dirck Barendsz, ${ }^{19}$ Otto van Veen, Frans Pourbus, Crispin van den Broeck, ${ }^{20}$ Bernaert de Rijckere, ${ }^{21}$ and Hendrick Goltzius. ${ }^{22}$ These artists used grisaille oil paintings on paper primarily as a means to prepare and define larger scale pictures; a grisaille was an intermediary step between a preliminary pen or chalk drawing and the finished oil painting. These works may also of course have served as presentation sheets that helped patrons understand what the finished picture would look like. Van Veen's grisaille study in oil for his large Martyrdom of Saint Andrew in the Sint-Andrieskerk in Antwerp is a good example. ${ }^{23}$ Another such sheet is a highly detailed grisaille on paper of the Last Judgment (private collection) that according to Müller Hofstede might be Jacob de Backer's preparatory modello for the middle panel of a triptych intended for the tomb of the prominent Antwerp printer, publisher, and bookbinder Christoph Plantin, who died in 1589 (OnzeLieve-Vrouwekathedraal, Antwerp). ${ }^{24}$ Artists like Otto van Veen also used monochrome oil sketches on paper as models for engravers. These sketches are usually less finished than presentation sheets because the collaborating engraver would often translate the painter's rough indications into the incised lines he required. The high degree of finish of the New York oil sketch therefore firmly excludes the possibility that it served as such a model.

As they did in the fifteenth century, in the days of Jan van Eyck and Rogier van der Weyden, in the late sixteenth century Netherlandish artists painted grisailles on canvas or panel for altarpieces as well as for private collectors. For example, the predella of The Madonna of Saint Luke that Marten de Vos painted in 1601-2 for the cathedral of

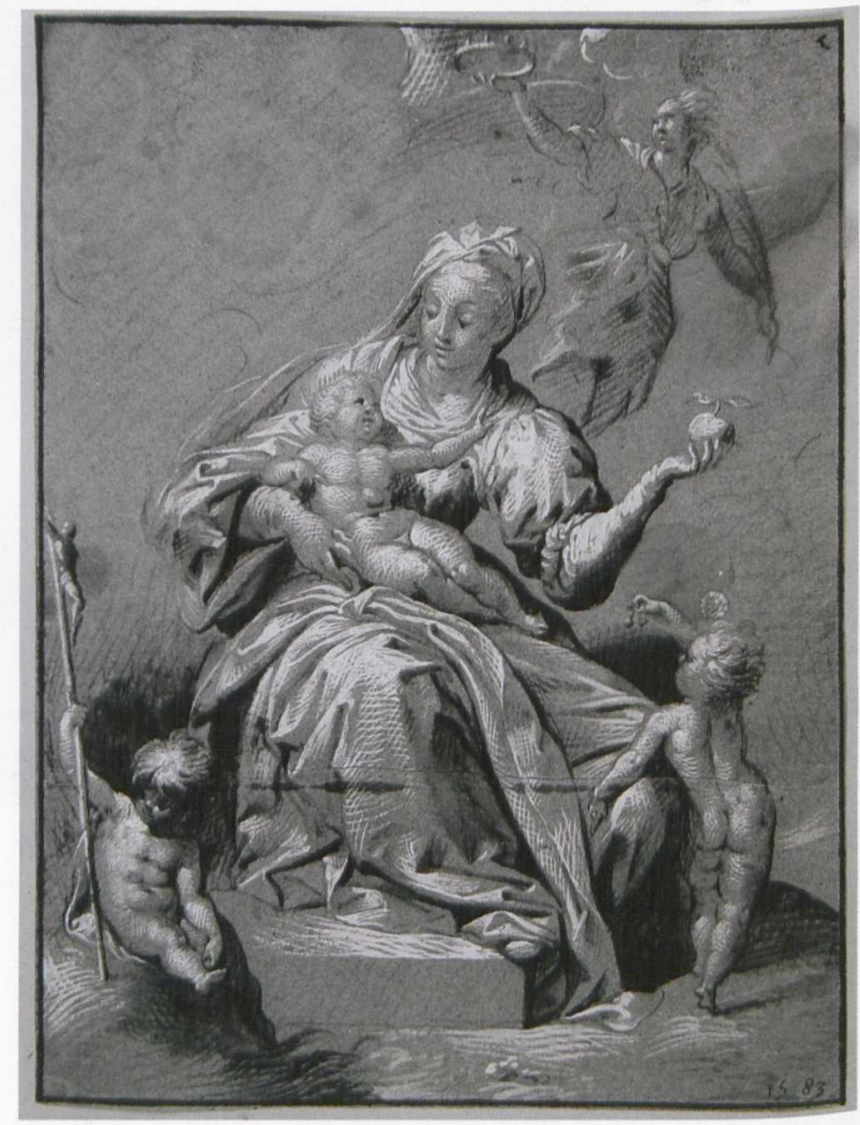

4. The De Backer group. Charity-Madonna. Black chalk with white heightening on blue paper, $115 / 8 \times 8 \frac{3 / 4}{4} \mathrm{in} .(29.6 \times 22.2 \mathrm{~cm})$. Staatliche Kunstsammlungen Dresden, Kupferstich-Kabinett (C533 in C 808,2) 
Antwerp (now Koninklijk Museum voor Schone Kunsten) consists of several grisaille scenes from the life of the patron of the painters' guild, the Guild of Saint Luke. ${ }^{25}$ Other monochrome pictures by Jacob de Backer are mentioned in the 1652 inventory of Victor Wolfoet's collection: number 86 is a grisaille painting of an unspecified subject ("a [picture] in black and white by Jacques de Backer on panel in a small frame"), ${ }^{26}$ and number 80 is a Danae on panel ("a Golden Rain by Jackques de Backer in black and white without a frame $\left.{ }^{\prime \prime}\right)^{27}$ that may well be identical with a grisaille painting on canvas now in the Kunsthistorisches Museum in Vienna (Figure 7). ${ }^{28}$ Another grisaille painting on canvas representing Susanna and the Elders (Figure 8) was recently auctioned as a work of Jacob de Backer. ${ }^{29}$ Once the New York oil sketch was mounted on panel, it must have been regarded as an independent work, the equivalent of such canvas or panel paintings.

In terms of iconography, the Metropolitan's Madonna and Child is a surprisingly complicated case. Foucart has in fact defined the subject of the painting in Boissise-laBertrand as a personification of Charity rather than a Madonna, citing the example of Andrea del Sarto's famous painting in the Louvre, Paris, the existence of which may even have been the reason for the Boissise-la-Bertrand picture's former attribution to that artist. ${ }^{30}$ Some of the more

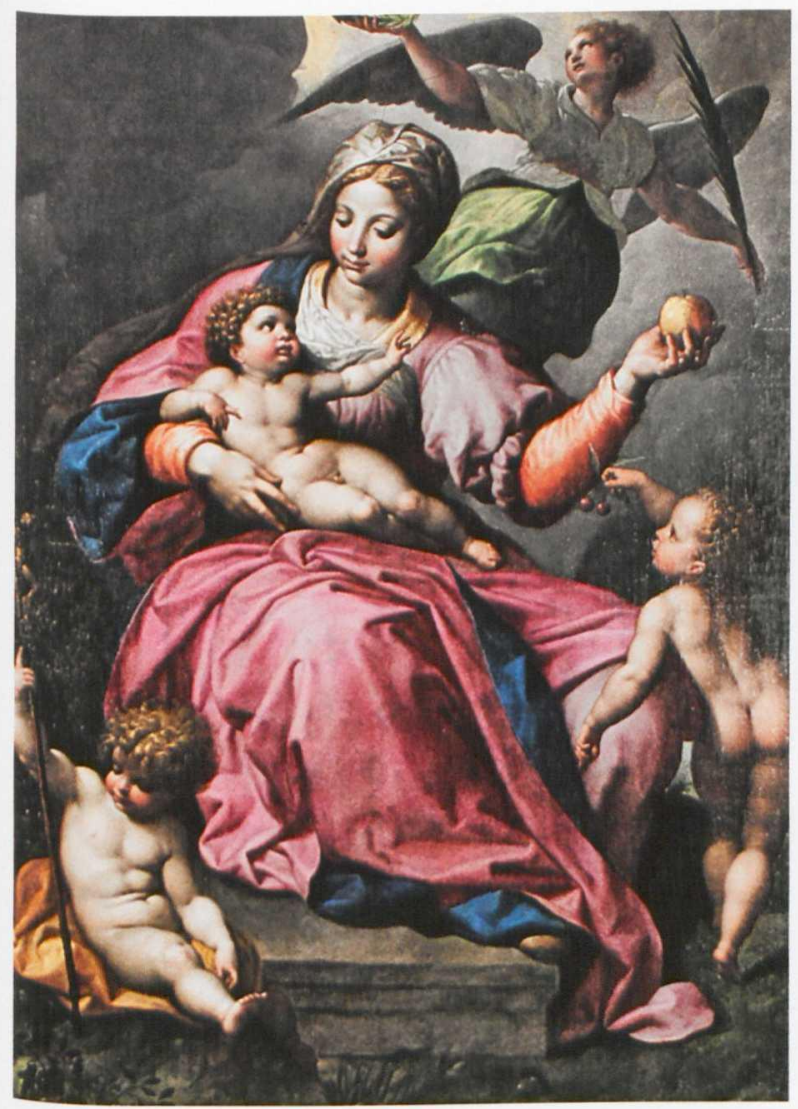

5. The De Backer group. Charity-Madonna. Oil on canvas, $661 / 8 x$ 52 in. $(168 \times 132 \mathrm{~cm})$. Church of Saint-Germain-d'Auxerre, Boissise-la-Bertrand, France unusual features of the composition, especially the standing child on the right, who does not appear in any of the period's more canonical representations of the Madonna with Child and Saint John, seem to confirm that alternate interpretation. Foucart was both right and wrong, however: the picture's composition is based on a typically Mannerist conceit in that it represents and confronts two closely related subjects at the same time, subjects that were both represented by wellknown painters such as Andrea del Sarto. ${ }^{31}$ Viewers who at first glance regarded the picture as a simple Madonna and Child would have been surprised by the additional figures and would soon have understood and even admired the allegorical complexity. In addition to their value as religious images, these pictures must have had a special appeal for contemporary art collectors (the Liefhebbers [lovers] of De Backer's art mentioned by Van Mander).

The iconology of this and several other paintings attributed to the De Backer group was as much the product of effective workshop practice as of considered theological or philosophical reflection. In the corpus of the De Backer group are several other pictures representing a woman seated in the center of the composition with two or three nude or seminude children next to her. These figures are more clearly allegories of Charity (Caritas) or Divine Wisdom (Sapientia divina). Divine Wisdom can be seen in a picture

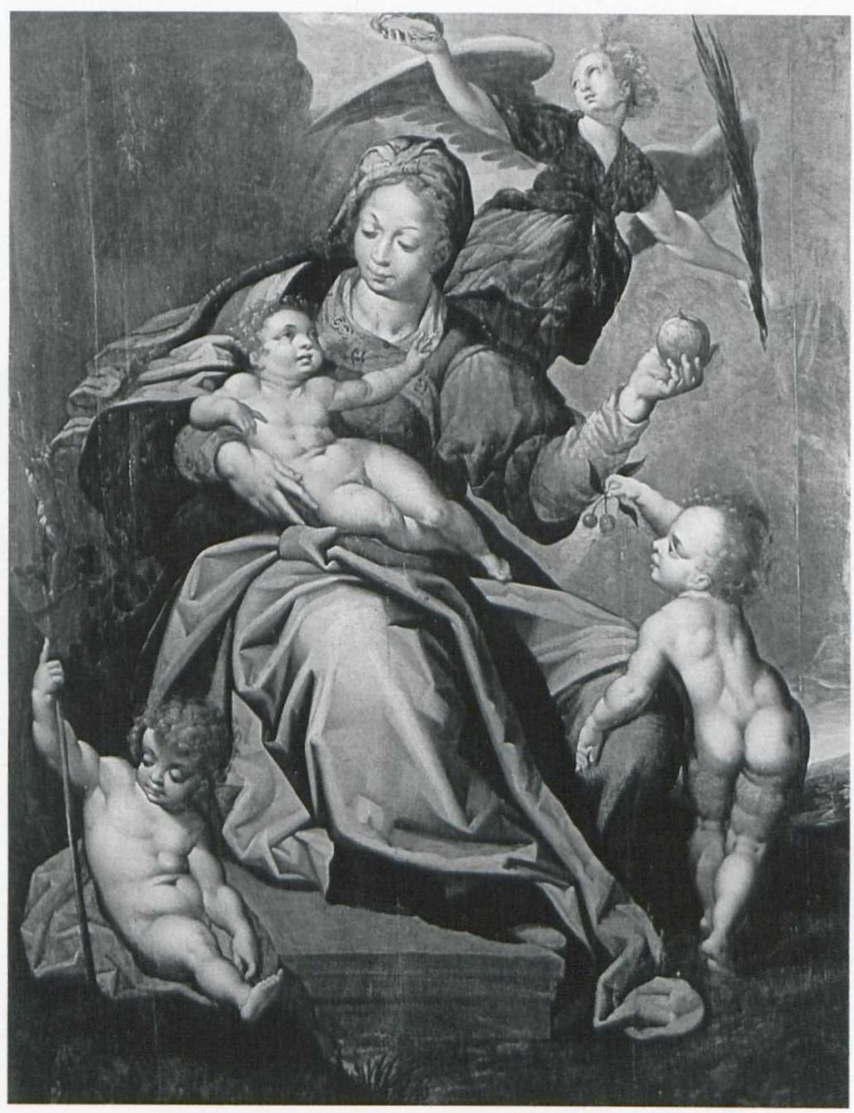

6. The De Backer group. Charity-Madonna. Oil on panel, $49 \times 38$ in. $(124.5 \times 96.5 \mathrm{~cm})$. Private collection. Photograph: courtesy Sotheby's 
7. The De Backer group. Danae. Oil on canvas, $243 / 8 \times$ $18 \frac{1}{8}$ in. $(62 \times 46 \mathrm{~cm})$. Kunsthistorisches Museum, Vienna

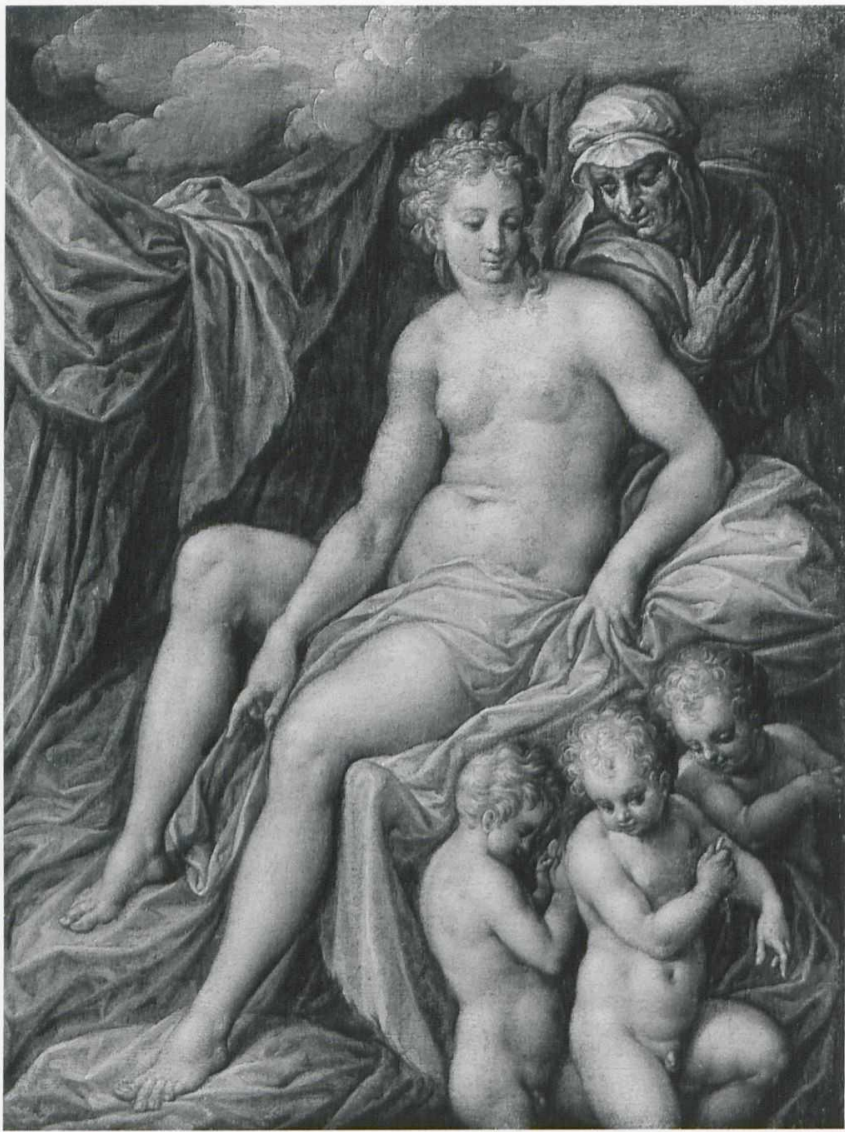

in the Nationalmuseum, Stockholm, ${ }^{32}$ and, in a slightly different arrangement, in another in the Staatsgalerie, Bamberg. ${ }^{33}$ The Bamberg picture, several other versions of which are known (see Figure 9), ${ }^{34}$ represents a young woman in an interior with a book on her lap who is pointing with her right hand at a mirror held by a genius crouching in the left foreground. Another child with an enormous torch stands to the right and another genius flying over the woman's head brings her a palm frond and a laurel(?) wreath with flowers. In several painted versions of Charity, the best known of which is in the Kelvingrove Art Gallery and Museum, Glasgow (Figure 10), ${ }^{35}$ the child on the right stands in almost the same pose as his counterpart in the Charity-Madonnas in New York (Figure 1) and Boissise-la-Bertrand (Figure 5), while the figure of Saint John with the crucifix has been replaced by a child standing on the left who holds a burning heart in his raised right hand. In another version of the Glasgow allegory that was auctioned in Paris in 2001 (Figure 11), the putto on the right presents the cherries to the infant Jesus with his left hand rather than with his right and an additional piece of cloth hangs over his shoulder. ${ }^{36}$ The most important difference between the Charities of the Glasgow type and the Charity-Madonnas is the man cowering at the feet of the seated woman, a figure with a money bag in his hand who can be interpreted as a personification of Avarice or, alternatively, as Judas. ${ }^{37}$

A painted Madonna of moderate quality in a private collection (Figure 12 ) $^{38}$ demonstrates that certain compositional features belonging to what must previously have been separate inventions could be freely combined. The seated Saint John holding the crucifix in the left foreground of that picture, for example, is directly related to the composition of the New York oil sketch, while the poses of Christ and the child on the right are quite different, and the seated woman not only has more matronly features but also looks up at the angel rather than looking down, as she does in most of the other versions. Another variant of the Glasgow Charity, last seen in an auction in 1933 (Figure 13), ${ }^{39}$ shows the standing putto on the right holding a mirror in his raised right hand that functions as

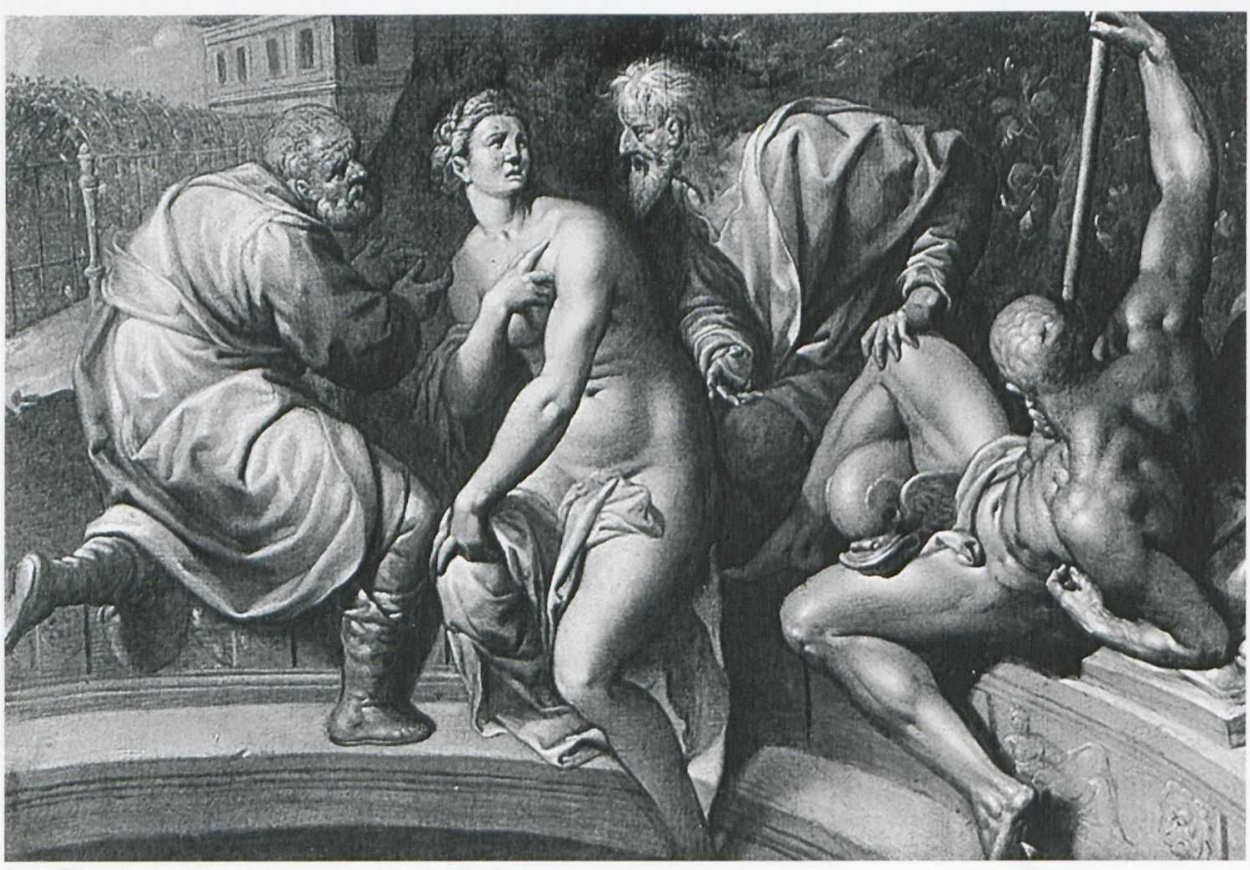

8. The De Backer group. Susanna and the Elders. Oil on canvas, $15 \times$ $22 \frac{1}{8}$ in. $(38.1 \times 56.2 \mathrm{~cm})$. Private collection. Photograph: courtesy Jan de Maere Gallery, Brussels 

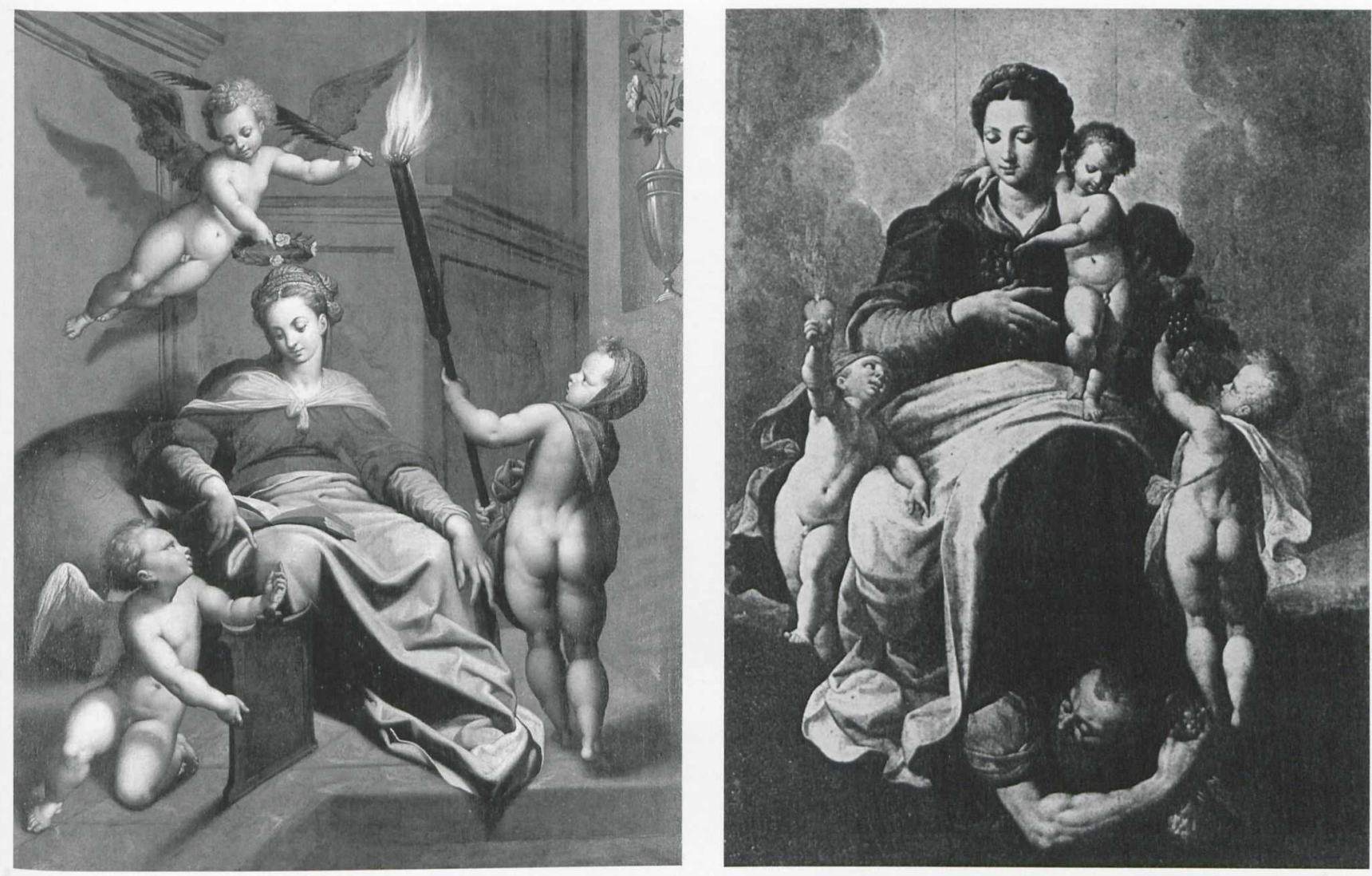

9. The De Backer group. Divine Wisdom. Oil on canvas, $54 \mathrm{x}$ $427 / 8$ in. $(137 \times 109 \mathrm{~cm})$. Private collection. Photograph: courtesy Sotheby's, London

10. The De Backer group. Charity. Oil on canvas, $331 \frac{1}{8} \mathrm{x}$ $243 / 8$ in. $(84.2 \times 61.8 \mathrm{~cm})$ Kelvingrove Art Gallery and Museum, Glasgow. Photograph: Giorgio T. Faggin, La pittura ad Anversa nel Cinquecento (Florence, 1968); fig. 170
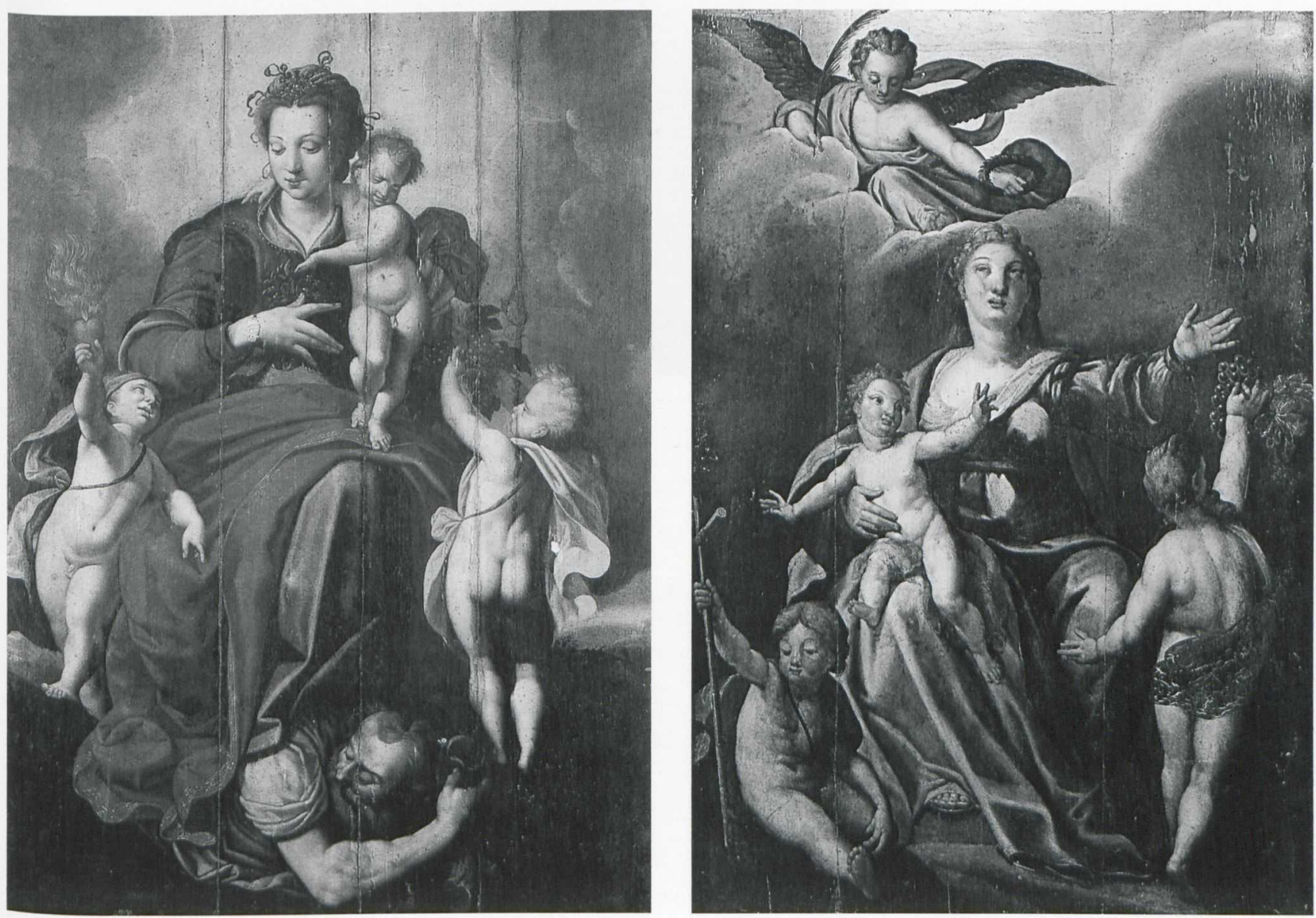

11. The De Backer group. Charity. Oil on panel, $401 / 8 x$ $283 / 8$ in. $(102 \times 72 \mathrm{~cm})$. Private collection. Photograph; courtesy Poulain le Fur, Paris

12. Circle of the De Backer group. Madonna and Child. Oil on panel, $42 \frac{1}{2} \times 297 / 8$ in. (108 x $76 \mathrm{~cm}$ ). Private collection. Photograph: courtesy Tajan, Paris 
13. The De Backer group. Charity-Madonna. Oil on wood, $325 / 8 \times 243 / 4$ in. $(83 \times$ $63 \mathrm{~cm}$ ). Whereabouts unknown. Photograph: sale catalogue, Hugo Helbig, Munich, June 27-28, 1933, pl. 4

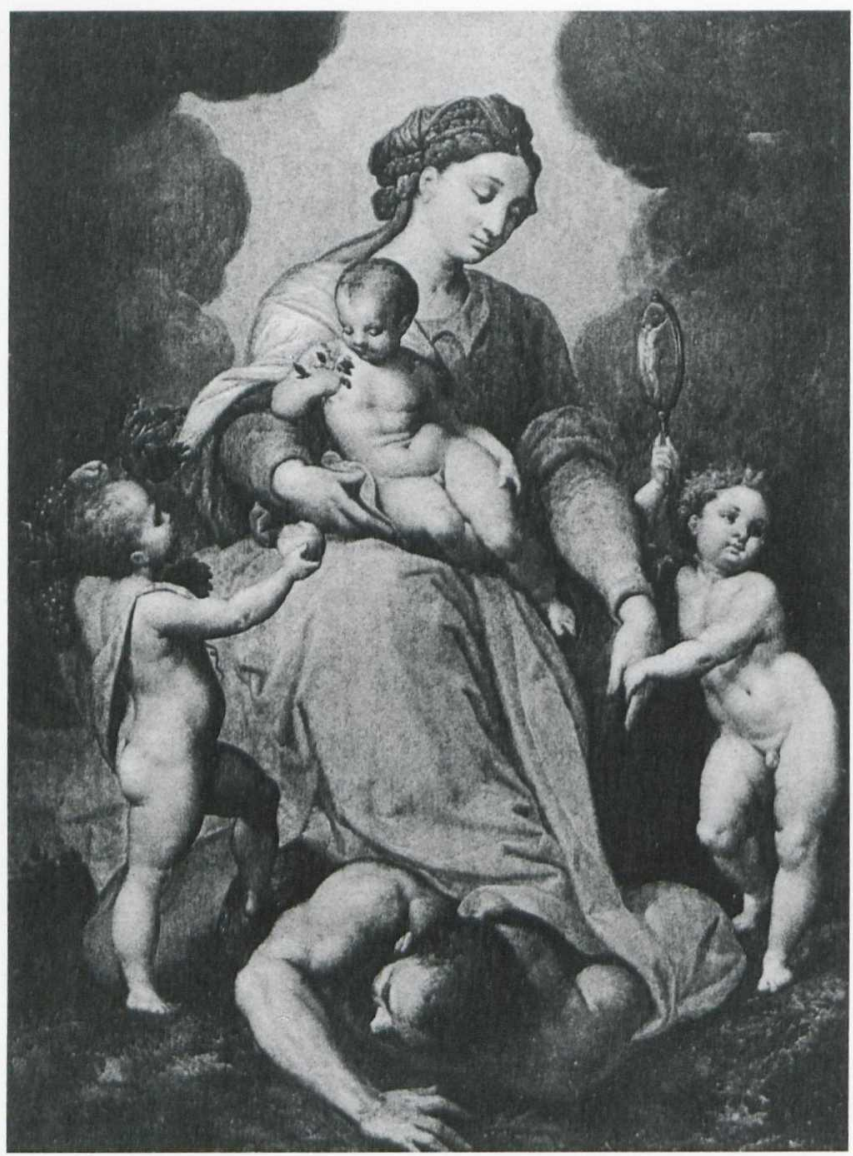

14. The De Backer group. Charity-Madonna. Oil on paper, $12 \% / 8 \times 10$ in. $(32.8 \times$ $25.4 \mathrm{~cm})$. British Museum, London (Ff 4.54)

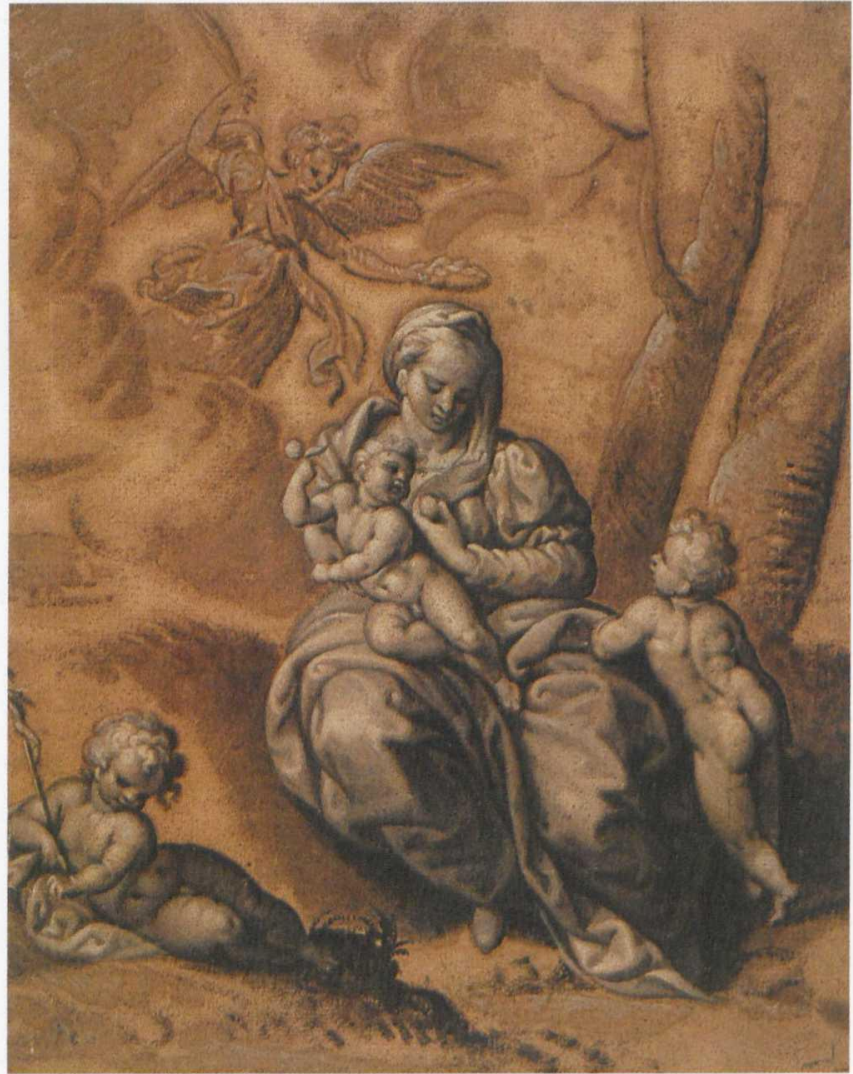

a kind of speculum passionis, reflecting the image of the crucified Christ.

There is little doubt that all of these repetitions, replicas, and variants were prepared with the help of painted models, or ricordi, of inventions that had previously been defined by the head of the workshop or cooperative of painters working in the same shop style, that is, by an artist who may be identifiable as Jacob de Backer. These models appear to have been executed both in pen and in oil; for example, a fragment of a pen drawing of the Baptism of Christ in the Louvre and attributed by the museum to an imitator of De Backer looks as if it was copied after a painting such as the Baptism of Christ in the Gemäldegalerie Alte Meister, Kassel, ${ }^{40}$ and was thus useful in the preparation of one or more replicas of that picture.

One wonders if such special editions and variations of existing compositions were not only the typical results of a production method based on the repetition of prototypes but were also ordered by individual clients. In other words, could compositions be adapted and assembled according to special needs from a kind of catalogue of motifs? An oil sketch on paper attributed to Jacob de Backer in the British Museum, London (Figure 14), for example, appears to be an adaptation of the painting in the Metropolitan Museum, an adaptation that most probably served as a new composition of yet another canvas or panel of the type best represented by the painting in Boissise-la-Bertrand (Figure 5). The economical reuse of figures and motifs exemplified by the London oil sketch was quite subtle. In fact, the pose of the infant Saint John lying in the left foreground is an imitation, with small variations, of the Christ Child lying on his mother's lap in the New York picture. The secondary status of the London sketch with respect to the painting in the Metropolitan is especially apparent in details such as John's right hand holding the crucifix, which is a direct but somewhat misplaced quotation of Christ's gesture in the painting.

While the London sketch conveys a clear impression of the generally good quality of the workshop that produced all or most of the De Backer group images, it also characterizes the daily routine of mass production in painters' workshops in late sixteenth-century Antwerp. Doing business on this semi-industrial scale meant that painters could create a model for a Charity and-after some minor adaptations - use it for a Divine Wisdom or a Madonna. This practice extended to compositions, originally separate, that were sometimes combined to form new images. The best of these patchwork compositions is a painting attributed to the circle of De Backer in the Stedelijk Museum Vander Kelen-Mertens, Leuven (Figure 15)..$^{41}$ Another version of the same composition (Figure 16), in which the putto standing on the right offers a bunch of small oranges and orange blossoms to the infant Christ 

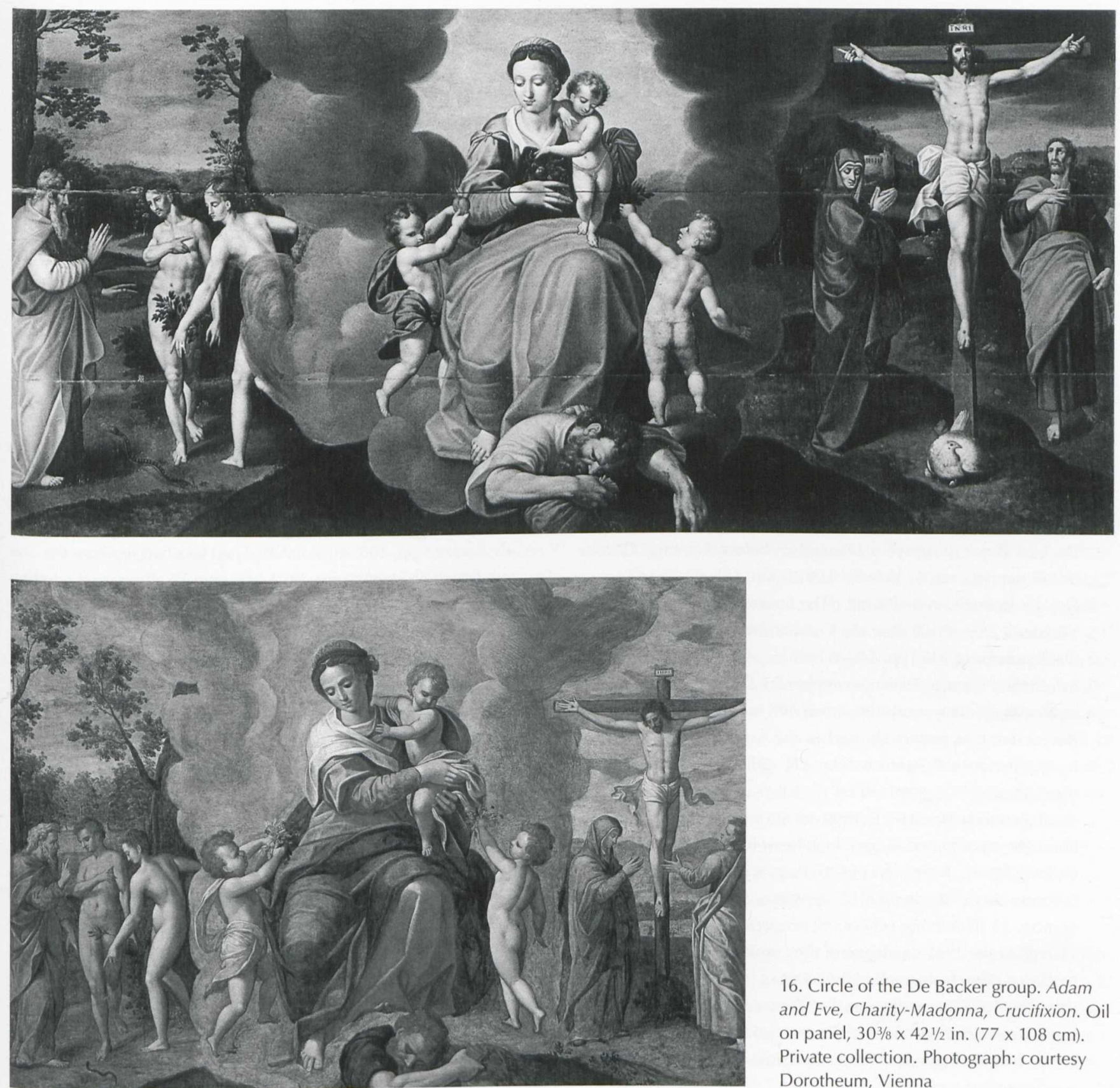

16. Circle of the De Backer group. Adam and Eve, Charity-Madonna, Crucifixion. Oil on panel, $30^{3 / 8} \times 42^{\frac{1}{2} / 2}$ in. $(77 \times 108 \mathrm{~cm})$. Private collection. Photograph: courtesy Dorotheum, Vienna
15. Circle of the De Backer group. Adam and Eve, Charity-Madonna,

Crucifixion. Oil on panel, $313 / 4 \times 671 \frac{1}{8}$ in. $(80.5 \times 170.5$ $\mathrm{cm})$. Stedelijk Museum Vander Kelen-Mertens, Leuven $(\mathrm{S} / 37 / \mathrm{O})$ (the sale catalogue explains this detail as an homage to William of Orange), was offered for sale in Vienna in 2000 and $2003 .{ }^{42}$

Huet has convincingly identified the Leuven picture as a compilation of three different inventions - an Adam and Eve, a Charity, and a Crucifixion-mentioned in Van Mander's Schilder-Boeck as separate paintings "half als t' leven" (half life-size) by Jacob de Backer in the collection of Melchior Wijntgis of Middelburg. ${ }^{43}$ But does this successful connection of an extant painting with attested works actually allow us a glimpse of the true De Backer? If this should prove to be the case, it is ironic that the only way to identify a painting mentioned by Van Mander as De Backer's is by conducting a study of a workshop compilation (or even a copy of a workshop compilation) of rather doubtful artistic quality. For an understanding of what made the art of Jacob de Backer, or rather the brand "Jacob de Backer and Co.," so ubiquitous and attractive to his contemporaries, the New York oil sketch offers a fresh starting point.

\section{ACKNOWLEDGMENTS}

I am grateful to Stijn Alsteens, associate curator in the Department of Drawings and Prints of The Metropolitan Museum of Art, for his helpful suggestions based on earlier versions of this paper and to Monroe Warshaw for first drawing my attention to the New York oil sketch. 
NOTES

1. Karel van Mander, Het Schilder-Boeck... (Haarlem, 1604), fols. 231v-232r; see Hessel Miedema, Karel van Mander: The Lives of the Illustrious Netherlandish and German Painters..., vol. 3 (Doornspijk, 1996), pp. 235-39.

2. Justus Müller Hofstede, "Jacques de Backer: Ein Vertreter der florentinisch-römischen Maniera in Antwerpen," Wallraf-RichartzJahrbuch 35 (1973), pp. 227-60; Leen Huet, "Jacob de Backer pictor olim famosus: Leven en wercken," MA thesis, University of Leuven, 1989.

3. See, for example, the long lists of replicas and copies of the two Last Judgments attributed to De Backer in Huet, "Jacob de Backer," pp. 46-53, 130-33.

4. See Eckhard Leuschner, "Ein unbekanntes Hauptwerk von Jacob de Backer in Meiningen," Jaarboek van het Koninklijk Museum voor Schone Kunsten Antwerpen, 1994, pp. 51-63; Eckhard Leuschner, "Antwerpener Akte: Zum Kontext eines Bildes von Jacob de Backer," Südthüringer Forschungen 29 (1996), pp. 5-21; and Eckhard Leuschner, "Defining De Backer: New Evidence on the Last Phase of Antwerp Mannerism before Rubens," Gazette des Beaux-Arts, ser. 6, 137 (April 2001), pp. 167-92.

5. See, for example, Amy Powell, "The Errant Image: Rogier van der Weyden's Deposition from the Cross and Its Copies," Art History 29 (September 2006), pp. 540-62.

6. Sale, Hôtel Drouot, Paris, November 23, 2001, lot 63. As is the case with so many works now assigned to the De Backer group, the picture was previously sold as the work of an Italian artist, in this instance Cristoforo Roncalli, called II Pomarancio, at the "house sale" organized by Christie's at Ca'n Puig in Palma de Mallorca on May 24-25, 1999 (lot 680). At the time of that sale the work was claimed to have long been in the possession of the Bellpuig family, the owners of Ca'n Puig. A painting with the same composition and identical dimensions, however, features as number 23 (Florentine school, oil on paper, $11 \times 8 \frac{1}{4}$ in. [27.9 $\times$ $21 \mathrm{~cm}]$ ) in the 1955 catalogue of the London-based dealer W. R. Jeudwine. The photograph of the painting in Jeudwine's catalogue shows that 1590 is inscribed on the Madonna's plinth. Stijn Alsteens has informed me that traces of this inscription are still visible in the New York painting, which firmly establishes that it is the work that was offered by Jeudwine.

7. Compare, for example, the nude figure of Juno in the Judgment of Paris of about 1560-70 in the National Gallery of Art, Washington, D.C., by an anonymous Netherlandish painter (Fiamminghi a Roma, 1508-1608: Artistes des Pays-Bas et de la principaute de Liège à Rome à la Renaissance, exh. cat., Palais des Beaux-Arts, Brussels; Palazzo delle Esposizioni, Rome [Brussels, 1995], pp. 421-22, no. 247). See also the child next to the female figure sometimes described as Venus in Jacopo Zucchi's Allegory of the Silver Age in the Uffizi, Florence (Magnificenza alla corte dei Medici: Arte a Firenze alla fine del Cinquecento, exh. cat., Palazzo Pitti, Florence [Milan, 1997], p. 200).

8. Foucart in Trésors sacrés, trésors cachés: Patrimoine des églises de Seine-et-Marne, exh. cat., Musée du Luxembourg (Melun, 1988), pp. 116-17, no. 39. See also Huet, "Jacob de Backer," pp. 109-11, no. A30. For Bronzino's Felicitas Publica, see Elena Capretti in Caterina Caneva and Francesco Solinas, eds., Maria de'Medici
(1573-1642): Una principessa fiorentina sul trono di Francia, exh. cat., Museo degli Argenti, Palazzo Pitti, Florence ([Livorno], 2005), p. 76 , no. 76 .

9. Manfred Sellink, comp., and Huigen Leeflang, ed., The New Hollstein: Dutch, and Flemish Etchings, Engravings, and Woodcuts, 1450-1700, [vol. 8], Cornelis Cort, part 1 (Rotterdam, 2000), pp. $126-33$, no. 40.

10. Huigen Leeflang et al., Hendrick Goltzius (1558-1617): Drawings, Prints, and Paintings, exh. cat., Rijksmuseum, Amsterdam; MMA; Toledo Museum of Art (Zwolle, 2003), p. 39, fig. 28. The influence of Barocci's composition is also apparent in Otto van Veen's Mystic Marriage of Saint Catherine, dated 1589 (Koninklijke Musea voor Schone Kunsten van België, Brussels, no. 240).

11. Sylvia Ferino-Pagden, Wolfgang Prohaska, and Karl Schütz, eds., Die Cemäldegalerie des Kunsthistorischen Museums in Wien: Verzeichnis der Gemälde (Vienna, 1991), p. 25, pl. 353.

12. It is attributed in the museum's inventory to Bartolomeo Coriolano.

13. Sale, Sotheby's, London, July 13, 1977, lot 191.

14. Foucart in Trésors sacrés, pp. 116-17, no. 39. See also Huet, "Jacob de Backer," pp. 109-11, no. A30. Huet lists two replicas, the one auctioned at Sotheby's in 1977 (see note 13 above) and another, the dimensions and support of which are unknown, offered for sale at the Paleis voor Schone Kunsten, Brussels, October 23-24, 1984 (Weltkunst 54 [1984], ill. p. 2508).

15. "Een stucxken van wit ende swert van Jacques de Backer wesende een Caritas op panneel in lyste," quoted in Erik Duverger, Antwerpse kunstinventarissen uit de zeventiende eeuw, vol. 6, 1649-1653 (Brussels, 1992), p. 345, no. 66.

16. See, for example, the chiaroscuro frescoes attributed to Stradanus in the Sala di Leone X in the Palazzo Vecchio (Alessandra Baroni, Jan van der Straet detto Giovanni Stradano: Flandrus pictor et inventor [Milan, 1997], p. 84), and his monochrome paintings in the church of Santo Stefano dei Cavallieri in Pisa (ibid., p. 172). Chiaroscuro oil or tempera painting on canvas was also employed for funeral decorations at San Lorenzo in Florence, in which case the choice of technique was clearly related to the need for a speedy execution of the pictures; see Monica Bietti, ed., La morte e la gloria: Apparati funebri medicei per Filippo II di Spagna e Margherita d'Austria, exh. cat., Cappelle Medicee, Florence (Livorno, 1999). One of the few "finished" (i.e., nonsketched) monochrome oil paintings on canvas made in Rome about 1600 is Giovanni Baglione's Resurrection of Christ (Louvre, Paris, R.F. 1964-28), the modello for the artist's lost monumental altarpiece in the Gesù (see Maryvelma Smith O'Neil, Giovanni Baglione: Artistic Reputation in Baroque Rome [Cambridge, 2002], p. 18, fig. 7).

17. The best analysis of the uses and functions of chiaroscuro oil sketches in sixteenth- and early seventeenth-century Netherlandish art remains Justus Müller Hofstede, "Zur Grisaille-Skizze in der Flämischen Malerei des XVII. und XVI. Jahrhunderts," in Beiträge zur Geschichte der Ölskizze vom 16. bis zum 18. Jahrhundert: Ein Symposion aus Anlass der Ausstellung "Malerei aus erster HandÖlskizzen von Tintoretto bis Goya" im Herzog Anton UlrichMuseum Braunschweig vom 28.-30.3. 1984, ed. Rüdiger Klessmann and Reinhold Wex (Brunswick, 1984), pp. 45-58. Müller Hofstede's stylistic distinction between less finished 
grisaille oils serving as models for a print and other, usually more elaborate oils that were preparatory studies for large canvas or panel paintings is especially useful.

18. Hans Buijs in Kunst voor de beeldenstorm: Noordnederlandse kunst, 1525-1580, ed. J. P. Filedt Kok, W. Halsema-Kubes, and W.Th. Kloek, exh. cat., Rijksmuseum, Amsterdam (Amsterdam, 1986), pp. 405-6, no. 296; Wouter Kloek, "De tekeningen van Pieter Aertsen en Joachim Beuckelaer," Nederlands Kunsthistorisch Jaarboek 40 (1989), pp. 160-62, nos. B.9a-B.9d. One of Beuckelaer's grisaille drawings, The Trickery of the Gibeonites, is now in the Getty Museum, Los Angeles (90.GG.133); see Lee Hendrix in J. Paul Getty Museum, European Drawings 3: Catalogue of the Collections (Los Angeles, 1997), pp. 190-91, no. 76.

19. On Barendsz's studies and their function(s), see Felice Stampfle, Netherlandish Drawings of the Fifteenth and Sixteenth Centuries and Flemish Drawings of the Seventeenth and Eighteenth Centuries in the Pierpont Morgan Library (New York, 1991), pp. 16-17, no. 28.

20. See Müller Hofstede, "Zur Grisaille-Skizze," figs. 6, 10, 12 (Van Veen), 13 (Pourbus), 15 (Van den Broeck). For the (nonmonochrome) studies in oil on paper by Frans Floris, see the discussion of an example by him in the Dresden Kupferstich-Kabinett in Christian Dittrich, Van Eyck, Bruegel, Rembrandt: Niederländische Zeichnungen des 15. bis 17. Jahrhunderts aus dem KupferstichKabinett Dresden, exh. cat., Albertinum, Dresden; Kunstforum Wien (Dresden, 1997), pp. 56-57, no. 19. A monochrome picture recently published with an attribution to Lambert van Noort in the Muzeum Narodowe, Wrocław, is a rare example of a preserved sixteenth-century Netherlandish oil painting on paper that must have been glued onto wood at an early date, perhaps right after production (see Bozena Steinborn, Muzeum Narodowe we Wrocfawiu: Catalogue of the Collection of Netherlandish Painting, 2d ed. (Wroctaw, 2006), pp. 330-31.

21. Département des Arts Graphiques, Louvre, 19304.

22. See the Sine Cerere et Libero friget Venus of 1599 in the British Museum, London (Leeflang et al., Hendrick Goltzius, p. 232, no. 83.2).

23. Müller Hofstede, "Zur Grisaille-Skizze," p. 50, fig. 6 (collection of the widow of Frans Baudouin).

24. Ibid., p. 55, fig. 16.

25. Armin Zweite, Marten de Vos als Maler: Ein Beitrag zur Geschichte der Antwerpener Malerei in der zweiten Hälfte des 16. Jahrhunderts (Berlin, 1980), pp. 318-20.

26. "Een van wit ende swert van Jacques de Backer op panneel in binnenlystken," quoted in Duverger, Antwerpse kunstinventarissen, vol. 6 , p. 345, no. 86 .

27. "Een stucxken van de Gulden Regen van Jacques de Backer van wit ende swert op panneel sonder lyste," quoted in ibid., no. 80.

28. Ferino-Pagden, Prohaska, and Schütz, Gemäldegalerie, p. 57, pl. 133. I have published this painting (Leuschner, "Unbekanntes Hauptwerk," fig. 2), which is related to a larger, polychrome version in the Bayerische Staatsgemäldesammlungen in Munich, as the work of a Netherlandish painter from the circle of Frans Floris of about 1570-90.

29. Sale, Kunstantiquariat Winterberg, Heidelberg, April 11-12, 2003, lot 37. The painting was previously offered at Christie's, London, on May 23, 2000, lot 115, and was exhibited at the Munich art fair in 2001 by the Jan de Maere Gallery, Brussels (Die Kunst-Messe München 46 [2001], p. 192). The nude man on the right (a sculptural decoration of Susanna's pool), with his complicated pose, can be compared with the river god in the Judgment of Paris in the State Castle, Český Krumlov, which was attributed to Jacob de Backer by Müller Hofstede in Ekkehard Mai and Hans Vlieghe, eds., Von Bruegel bis Rubens: Das goldene Jahrhundert der flämischen Malerei, exh. cat., Wallraf-Richartz-Museum, Cologne; Koninklijk Museum voor Schone Kunsten, Antwerp; and Kunsthistorisches Museum Wien, Vienna (Cologne, 1992); pp. 259-60. The style of both paintings, however, differs from the solid figures and economical picture planes of most of the works attributed to the De Backer group; they may thus be products of a workshop collaborator whose compositions are somewhat more complicated but less well organized.

30. Foucart in Trésors sacrés, p. 116. For Andrea del Sarto's picture in Paris, see Antonio Natali, Andrea del Sarto: Maestro della maniera moderna (Milan, 1998), p. 98, fig. 82.

31. For Andrea del Sarto's Madonna-like Carità in the Chiostro dello Scalzo in Florence, see Natali, Andrea del Sarto, p. 64, fig. 55. As del Sarto's fresco was adapted in a composition variously attributed to Cornelis van Cleve or Vincent Sellaer (Stiftung SchleswigHolsteinische Landesmuseen Schloss Gottorf, and see another version offered at the sale at Galerie Koller, Zurich, March 22-24, 2003 , lot 1), its composition appears to have been available in the Netherlands prior to the beginnings of De Backer's career.

32. Astrid Tydén-Jordan, "Sapientia Divina, en motreformert propagandamaling av Jacques de Backer," Konsthistorisk tidskrift 52 (1983), pp. 64-74, fig. 1. A related composition, probably an allegory of the Ecclesia Militans $(487 / 8 \times 373 / 8$ in. [124 × $95 \mathrm{~cm}])$, was auctioned on April 29, 1994, by Étienne et Damien Libert and Alain Castor at Drouot-Richelieu, Paris, with an attribution to Jacques de Backer (Gazette Drouot 17 [1994], p. xI).

33. Huet, "Jacob de Backer," pp. 53-55, no. A4 (oil on panel, 413/4 X $31 \frac{1}{8}$ in. [106 $\left.\left.\times 79 \mathrm{~cm}\right]\right)$.

34. A good version (Figure 9) was for sale at Sotheby's, London, December 9, 2004, lot 102 (and previously at Christie's, New York, October 9, 1991, lot 194). A drawing that most probably is a copy after yet another version of the composition is in the Louvre (22080; Frits Lugt, Musée du Louvre. Inventaire général des dessins des écoles du Nord: Maîtres des anciens Pays-Bas nés avant 1550 [Paris, 1968], no. 702, pl. 200; Müller Hofstede, "Jacques de Backer," p. 227, fig. 24).

35. Tydén-Jordan, "Sapientia Divina," p. 66, fig. 2; Huet, "Jacob de Backer," pp. 93-94, no. A22. The picture was presented to the museum in 1854 as a work by Primaticcio.

36. Sale, Poulain le Fur, Paris, June 21, 2001, lot 29, and December 16, 2001, lot 17 (as attributed to Jacob de Backer).

37. The interpretation of the bearded man with the purse as Avarice is due to Müller Hofstede; Judas is a suggestion advanced by Huet (see note 2 above).

38. Sale, Tajan, Paris, October 27, 2006, lot 39 (as "Studio of Jacques de Backer"). Another version of this composition with a few variations and an attribution to a "follower of Jacob de Backer" was auctioned at Sotheby's, London, October 30, 2008, lot 4.

39. Sale, collection of Ludwig Benz (Tutzing), Hugo Helbig, Munich, June 27-28, 1933, lot 239 (as "Otto van Veen"). 
40. Müller Hofstede, "Jacques de Backer," p. 241; Bernhard Schnackenburg, Staatliche Museen Kassel, Gemäldegalerie Alte Meister: Gesamtkatalog, 2 vols. (Mainz, 1996), vol. 1, p. 43. The drawing in the Louvre (21.230) is currently catalogued as a copy after De Backer (Lugt, Musée du Louvre, no. 703).

41. Huet, "Jacob de Backer," pp. 94, 136, no. B5.

42. Sale, Dorotheum, Vienna, June 7, 2000, lot 129, and (apparently after some cleaning and restoration work) October 1, 2003, lot 83.
See also the Madonna with Child and Two Putti in the Muzeum Narodowe, Wrocław (oil on wood, $42 \frac{1}{1} 2 \times 30$ in. [108 $\left.\times 76.2 \mathrm{~cm}\right]$ ), a picture recently published by Steinborn (Muzeum Narodowe, p. 281) as an Allegory of Charity and attributed to Jacob de Backer.

43. "Een Adam en Eva, een Charitas en een crucifix" (Van Mander, Schilder-Boeck, fol. 232r, and see Huet, "Jacob de Backer," pp. 93-95). 